\title{
SOCIO-ECONOMIC AND COMMUNICATION CHARACTERISTICS OF \\ FARMERS AND FARM WOMEN IN CLIMATE VULNERABLE \\ REGIONS OF UTTARAKHAND STATE, INDIA
}

\author{
ANJALI CHUNERA $^{1} \&$ AMARDEEP ${ }^{2}$ \\ ${ }^{I}$ Research Scholar, Department of Agricultural Communication, College of Agriculture, \\ G. B Pant University of Agriculture and Technology, Uttarakhand, India \\ ${ }^{2}$ Associate Professor, Department of Agricultural Communication, College of Agriculture, \\ G. B Pant University of Agriculture and Technology, Uttarakhand, India
}

\begin{abstract}
Uttarakhand is a hill-state with agriculture as the mainstay of rural livelihoods and rural economy. Most of the economic and livelihood sectors of the state are exceedingly dependent on the biodiversity and natural resources of the state thus making them vulnerable to climate change, as climate change will have direct impacts on livelihoods of the people. So, it is very important to assess the impact of climate change on farmers and develop extension strategies to manage the ecosystem and conserve the biodiversity. For doing these it is very important to know about the life and living of the farmers and farm women separately from this area. The main focus of this study is to elucidate and compare the socioeconomic characteristics of farm women and male farmers as well as identify and describe the factors responsible for the different socioeconomic characteristics of the farmers. Significant differences were found between male farmers and farm women in the aspects of education, age, secondary occupation, income groups, information seeking behavior, training exposure, social participation and agricultural land holdings.

KEYWORDS: Agriculture, Socio-Economic Characteristics, Communication, Farmer, Farm Women \& Climate Change
\end{abstract}

Received: Jun 15, 2018; Accepted: Jul 06, 2018; Published: Jul 28, 2018; Paper Id: IJASRAUG20188

\section{INTRODUCTION}

Uttarakhand is a hill-state and has unique biophysical and insubstantial geographical conditions due to which conventional development such as the development of industries and infrastructures needed for service sector cannot take place; therefore, agriculture is the mainstay of rural livelihoods and rural economy. Most of the economic and livelihood sectors of the state are exceedingly dependent on the biodiversity and natural resources of the state thus making them vulnerable to climate change, as climate change will have direct impacts on livelihoods of the people. Since last few decades, Uttarakhand is facing unpredictable weather conditions. The state experienced a sequence of floods, cloudburst, and droughts with a change in the rainfall pattern in the area between 2006 and 2008 which affected crops, animals and people's livelihoods expansively (Mele, 2009).

The share of agriculture sector in Gross State Domestic Product (GSDP) has been declined from 29 per cent in 2000 to 14.73 per cent in 2013 (Directorate of Economics and Statistics, Uttarakhand, 2014) and major reason for this declining percentage are the erratic climate change scenario and outmigration. The major reasons 
behind the vulnerability of Uttarakhand's agriculture to climate change are its dependence on rain, rugged and steep topography, poor infrastructure, the dominance of marginal land holdings, limitation of use of farm machinery in hill areas, higher cost of production for agriculture in the hills and rapid migration. Moreover, being a mountain state its social context characterizes with a low level of institutional capacity consequent to intensify the impact of atmospheric changes. The people of Uttarakhand face multiple hazards as Uttarakhand suffers a very high exposure risk of river flood, landslides, cloudburst, hail storms etc. Consequently, people livelihoods depend on natural resources, they have limited options for diversifying their livelihoods, have low levels of assets, and little capacity to transform their asset into income, (Government of Uttarakhand, UAPCC. 2014).

The immediate and long-term impacts of climate change in Uttarakhand are distressing people in varying degrees. Due to the low production of crops and high loses the men population has mainly migrated to the plain region for seeking opportunity for earning for livelihood. The people left behind are old age men, women and children. Women are more burdened with the additional responsibility of carrying out agriculture alone along with earlier household chores. Apart from this abrupt weather conditions poses extra trouble by harming their crop production and thus leading to high loses and more work. They face a host of challenges that range from heavy workloads to limited access to financial, livelihood and health services, and with limited or no control over productive resources and decision-making processes, (Leduc, 2011). The men, on the other hand, are not exempted from the consequences of climate change. As the men left behind have less support left, limited income and responsibility of general well being of the family, as men are generally regarded as household heads. These also have the potential to bring about increase the vulnerability of men to climate change impacts.

It is clear that climate change affects everyone, but the intensity differs according to the vulnerability and coping abilities. Climate change impacts both men and women, but differently. So, it is very important to assess the impact of climate change on farmers and develop extension strategies to manage the ecosystem and conserve the biodiversity. For doing these it is very important to know about the life and living of the farmers and farm women separately from this area. The main focus of this study is to elucidate and compare the socioeconomic characteristics of farm women and male farmers as well as identify and describe the factors responsible for the different socioeconomic characteristics of the farmers.

\section{MATERIALS AND METHODS}

The present study was conducted in the hilly region of Uttarakhand state during the year 2017-2018. Two hill district of the state i.e. 'Bageshwar' and 'Tehri Garhwal' were selected purposively as the locale of the study on the basis of high vulnerability of agriculture to climate change. These two districts were ranked first and second highest vulnerable districts among all districts of Uttarakhand as stated in Atlas on Vulnerability of Indian Agriculture to Climate Change by Central Research Institute for Dryland Agriculture, 2013. Sampling was done through Multi-stage sampling method. At stage first one block of each district, i.e. Chamba block from Tehri Garhwal and Bageshwar block from Bageshwar district were selected through Simple random sampling without replacement. At the second stage, three villages from each block were selected through Simple random sampling without replacement. From Chamba block of Tehri Garhwal district, Sabali Talli, Sabali Malli, and Jagdhar were selected while from Bageshwar block of Bageshwar district, Simkuna, Bhandarisera, and Bhandarigaon were selected. At the final stage i.e. selection of respondents, total 300 farmers and farm women were selected through Probability Proportionate to Size method from the villages. 50\% male and female were 
Farmers and Farm Women in Climate Vulnerable

Regions of Uttarakhand State, India

selected out of total respondent i.e. 150 farm women and 150 male farmers. The descriptive research design was used for conducting the research. Semi-structured interview schedule and non-participant observation were used for collecting the information. Socio-economic status and communication characteristic was measured using variables likeage, gender, education, caste, secondary occupation, total family income, farming experience, agricultural landholding, social participation, farm equipment possession, livestock possession, information seeking behavior, training-exposure using appropriate scales.

\section{RESULTS AND DISCUSSIONS}

\section{Socio-Economic and Communication Characteristics of Male Farmers and Farm Women}

The main focus of this paper is investigating farmers and farm women's socio-economic and communication characteristics of different climate vulnerable regions of Uttarakhand state, India. For this study an equal number of farmers and farm, women were taken as respondents i.e. 150 farmers and 150 farm women. It is evident from Table 1 that regarding age not much of a difference was observed, a majority of respondents were of middle-aged group (66.33\%) out of which 31.67 percent were farm women while 34.67 per cent were male farmers. The lower percentage of young age group was observed in male farmers due to the fact that they usually migrate in the search of livelihood to the plain areas leaving females behind. The findings of the present study are in line with Singh and Mishra (2012) and Rastogi and Hasan (2014) who reported that the majority of the respondents were middle-aged.

The literacy level among the farmers in the areas reveals that a high percentage of respondents studied up to the primary and middle school level. Very less number of respondents had education up to graduation and above. The data from Table 1 reveals that 14.33 per cent were illiterate but out of which the share of farm women was more (10.33\%) than male farmers $(4 \%)$. Out of the total population of farm women, 20.67 per cent were illiterate while for male farmers this figure was very low (8\%). Differences were also observed in higher educational level. It was found that males farmers had a higher educational level than farm women. Probable reasons behind low educational level in farm women were the fewer opportunities of education for respondents due to the poor educational facilities available in hilly remote areas, an absence of schools in the village or nearby villages, low interest in education and pressure to perform household chores since the early age by families.

Socioeconomic indicators of the respondents further indicate that not much difference was observed regarding caste among farm women and male farmers. It was found that majority of respondents $(67.33 \%)$ were of upper caste followed by 32.67 per cent of respondents belonged to lower caste. It was noticed that 64.67 percent of the farm women belonged to upper caste and $70 \%$ of male farmers belonged to the upper caste. 35.33 per cent of farm women and 30 per cent male farmer belonged to a lower caste. None of the respondents were found to be in middle caste. As the primary occupation of respondents was agriculture, a secondary source of respondents was analyzed and it was found that majority of the respondents $(36.34 \%)$ were not involved in any secondary occupation. It was observed that more than farm women (50 \%), male farmers were more involved in secondary occupation $(77.33 \%)$ like animal husbandry, service/job, wage earner, business. Most opted secondary occupation for women was animal husbandry while for male farmers it was business. The reason for non-involvement of farm women in any secondary occupation might be the lack of access to the market, services, facilities, network and lack of awareness. Moreover, huge difference in family income was also observed as most of the farm women (36\%) belonged to the lower income group while male farmers belonged to an upper middle group (34\%). Most of the farm women $(70 \%)$ and male farmers $(64 \%)$ had a medium level of farming experience. 
In addition, 100 per cent of farm women belonged to marginal farmers group while regarding male farmers 82 per cent of them were marginal farmers, the rest $18 \%$ belonged to medium farmer group with an agricultural landholding of more than 2 hectares. The study also finds support from the findings of Rastogi and Hasan (2014) who found that the majority of the farmers were possessing small land holding size. Furthermore, findings reveal that 68.67 per cent of farm women were not a member of any organization/society while $50 \%$ of male farmers were not involved in any of the organization/society. While 10 per cent of the male farmers were the office bearer of one or more society/ organization, only 6.67 per cent farm women were the office bearer of one or more society/ organization. The low involvement in any society/organization was due to the fact that women were more involved in their reproductive and productive tasks that they usually do not get time for other activities. Livestock possession was low for both farm women (33.33 \%) and male farmers (34.34). The farm equipment used by the hill farmers and farm women were sickle, plow, shovel and land leveler. Sickle and shovel were owned by each of them while land leveler was owned by 80.67 per cent of farm women and 95.33 per cent of male farmers. Plough was owned by 34.67 per cent and 45.33 per cent of male farmers. The findings of the present study are in line with, (Raghuvanshi, 2015) who reported that most owned farm equipment in the hilly region of Uttarakhand are sickle and shovel and a majority of the respondents possess less number of livestock.

While studying the communication indicator it was found that almost half $(54.67 \%)$ of the farm women had a low level of information seeking behavior and the majority of male farmers (66\%) had a medium level of information seeking behavior. It was observed that farm women had low to medium level and male farmers had medium to high information seeking behavior. Furthermore, regarding the training exposure, it was found that 70 per cent of farm women and 58.67 per cent male farmers had no training exposure. The high accessibility and control over services made it easier for male farmers to take training.

\section{CONCLUSIONS}

From the results it is evident that farm women had low socioeconomic status than male farmers in the Uttarakhand region as they had low educational level than male farmers, they were younger, were not involved in any secondary occupation, they belonged to lower income groups than male farmers. Also, they were behind male farmers in information seeking behavior, training exposure, social participation and agricultural land holdings. But it was also found that they were almost equal in livestock possession, farm equipment possession, and farming experience. The reason behind farm women lagging back, in spite of working more than male farmers in their lack and control over resources, facilities, and services. As farm women and male farmer's socioeconomic status and communication characteristics are very different therefore while assessing the impact of climate change and designing policies and programmes this difference should be kept in mind in order to mitigate constraints of farm women.

\section{REFERENCES}

1. Uttarakhand at a Glance (2014), Directorate of Economics and Statistics, Dehradun, Uttarakhand. Retrieved from http://des.uk.gov.in/

2. (Government of Uttarakhand, UAPCC. 2014). Uttarakhand Action Plan on Climate Change. Retrieved from http://www.moef.gov.in/sites/default/files/Uttarakhand\%20SAPCC.pdf

3. Leduc, B. (2011). Mainstreaming gender in mountain development: from policy to practice. Lessons learned from a gender assessment of four projects implemented in the Hindu Kush-Himalayas. International centre for integrated mountain development (ICIMOD). 
Farmers and Farm Women in Climate Vulnerable

Regions of Uttarakhand State, India

4. Tiwari, Mradula, Ritu Chakravarty, And Jayant Goyal. "Availability And Accessibility Of Information Communication Technology (Ict) Among Dairy Farmers In Uttarakhand, India." (2014).

5. Mele, S. (2008). Climate Change study in Uttarakhand, (Himalayan Region) India. Retrieved from http://www.wfooma.com/climate-change/case-studies/climatechange-study-in-uttarakhand-india.html.

6. Raghuvanshi, R. (2015). A study on awareness about climate change and adaptation of agricultural practices by farmers in Uttarakhand (Unpublished Master's thesis). Govind Ballabh Pant University of Agriculture and Technology, Udham Singh Nagar, Uttarakhand, India.

7. Rastogi, S. and Hasan, S. (2014). A study on communication behaviour of agricultural input users of Udham Singh Nagar district of Uttarakhand, India. Journal of Applied and Natural Science, 6 (1), 193-196

8. Haile, F. I. R. A. F. I. S. "Factors affecting women famer's participation in agricultural extension services for improving the production in rural district of DENDI WEST SHOA ZONE." (2016).

9. Singh, D. K. and Mishra, O. P. (2012). Information Need of Rural Families in Ballia District of Uttar Pradesh. Journal of Communication Studies, 30 (1), 151-157

10. Singh, S. (2014). Women, Environment and Sustainable Development: A Case Study of Khul Gad Micro Watershed of Kumoun Himalaya, Space and Culture, India, 3, 53-64

\section{APPENDICES}

Table 1: Distribution of Respondents According to Socio-Economic Characteristics ( $\mathbf{N = 3 0 0 )}$

\begin{tabular}{|c|c|c|c|c|c|c|}
\hline \multirow[b]{2}{*}{ Variable } & \multirow{2}{*}{$\begin{array}{c}\text { Frequency } \\
(\mathbf{N}=\mathbf{3 0 0})\end{array}$} & \multirow[b]{2}{*}{ Percentage } & \multicolumn{2}{|c|}{ Farm Women } & \multicolumn{2}{|c|}{ Farmer } \\
\hline & & & $\begin{array}{l}\text { Frequency } \\
(\mathbf{n}=150)\end{array}$ & $\%$ & $\begin{array}{l}\text { Frequency } \\
(\mathbf{n}=150)\end{array}$ & $\%$ \\
\hline \multicolumn{7}{|c|}{ Socio-Economic Characteristics: } \\
\hline \multicolumn{7}{|c|}{ Age (years) } \\
\hline Young (Up to 34 years) & 56 & 18.66 & 34 & 22.67 & 22 & 14.67 \\
\hline Middle-aged (35 - 61 years) & 199 & 66.33 & 95 & 63.33 & 104 & 69.33 \\
\hline Old (More than 61 years) & 45 & 15 & 21 & 14 & 24 & 16 \\
\hline \multicolumn{7}{|c|}{ Education } \\
\hline Illiterate & 43 & 14.33 & 31 & 20.67 & 12 & 8 \\
\hline Primary & 98 & 32.67 & 51 & 34 & 47 & 31.33 \\
\hline Middle & 62 & 20.67 & 37 & 24.67 & 25 & 16.67 \\
\hline Higher school & 40 & 13.33 & 11 & 7.33 & 29 & 19.33 \\
\hline Intermediate & 45 & 15 & 17 & 11.33 & 28 & 18.67 \\
\hline Graduate and above & 11 & 3.67 & 3 & 2 & 8 & 5.33 \\
\hline Post graduate & 1 & 0.33 & 0 & 0 & 1 & .67 \\
\hline \multicolumn{7}{|c|}{ Caste } \\
\hline Upper caste (General) & 202 & 67.33 & 97 & 64.67 & 105 & 70 \\
\hline Middle caste (OBC) & 0 & 0 & 0 & 0 & 0 & 0 \\
\hline Lower caste (SC/ST) & 98 & 32.67 & 53 & 35.33 & 45 & 30 \\
\hline \multicolumn{7}{|c|}{ Secondary Occupation } \\
\hline None & 109 & 36.34 & 75 & 50 & 34 & 22.67 \\
\hline Wage earner & 40 & 13.33 & 17 & 11.34 & 23 & 15.33 \\
\hline Animal Husbandry & 99 & 33 & 48 & 32 & 51 & 34 \\
\hline Service/job & 19 & 6.33 & 2 & 1.33 & 17 & 11.33 \\
\hline Business & 33 & 11 & 8 & 5.33 & 25 & 16.67 \\
\hline \multicolumn{7}{|c|}{ Family Income } \\
\hline $\begin{array}{l}\text { Extreme Lower Income } \\
(<\text { Rs. } 33000 \text { p.a. })\end{array}$ & 29 & 9.67 & 20 & 13.33 & 9 & 6 \\
\hline $\begin{array}{l}\text { Lower Income } \\
\text { (Rs. } 33001 \text { - Rs. } 55000 \text { p.a.) }\end{array}$ & 77 & 25.67 & 54 & 36 & 23 & 15.33 \\
\hline $\begin{array}{l}\text { Lower Middle Income } \\
\text { (Rs. } 55001 \text { - Rs. } 88800 \text { p.a.) }\end{array}$ & 86 & 28.67 & 47 & 31.34 & 39 & 26 \\
\hline
\end{tabular}




\begin{tabular}{|c|c|c|c|c|c|c|}
\hline \multicolumn{7}{|c|}{ Table 1: Contd., } \\
\hline $\begin{array}{l}\text { Upper Middle Income } \\
\text { (Rs. } 88801 \text { - Rs. } 150000 \text { p.a.) }\end{array}$ & 75 & 25 & 24 & 16 & 51 & 34 \\
\hline $\begin{array}{l}\text { Higher Income } \\
\text { (>Rs. } 150000 \text { p.a.) }\end{array}$ & 33 & 11 & 5 & 3.33 & 28 & 18.67 \\
\hline \multicolumn{7}{|c|}{ Farming Experience } \\
\hline Low ( up to 14 years) & 56 & 18.67 & 24 & 16 & 32 & 21.33 \\
\hline Medium (14-32 years) & 201 & 67 & 105 & 70 & 96 & 64 \\
\hline High (more than 32 years) & 43 & 14.33 & 21 & 14 & 22 & 14.67 \\
\hline \multicolumn{7}{|c|}{ Agricultural landholding } \\
\hline $\begin{array}{l}\text { Small Farmer/Marginal } \\
\text { Farmer }(<=2 \text { hectare })\end{array}$ & 273 & 91 & 150 & 100 & 123 & 82 \\
\hline $\begin{array}{l}\text { Medium farmer } \\
(>2 \text { hectare) }\end{array}$ & 27 & 9 & 0 & & 27 & 18 \\
\hline Large farmer( $>5$ hectare $)$ & 0 & 0 & 0 & & 0 & \\
\hline \multicolumn{7}{|c|}{ Social Participation } \\
\hline $\begin{array}{l}\text { Not a member of any } \\
\text { organization/society }\end{array}$ & 178 & 59.33 & 103 & 68.67 & 75 & 50 \\
\hline $\begin{array}{l}\text { Member of only one } \\
\text { society/ organization }\end{array}$ & 70 & 23.33 & 33 & 22 & 37 & 24.67 \\
\hline $\begin{array}{l}\text { Member of more than one } \\
\text { society/ organization }\end{array}$ & 27 & 9 & 4 & 2.66 & 23 & 15.33 \\
\hline $\begin{array}{l}\text { Office bearer of one or } \\
\text { more society/ organization }\end{array}$ & 25 & 8.33 & 10 & 6.67 & 15 & 10 \\
\hline \multicolumn{7}{|c|}{ Livestock Possession } \\
\hline Low (Less than 4) & 203 & 67.67 & 100 & 33.33 & 103 & 34.34 \\
\hline Medium (4 to 8 ) & 78 & 26 & 45 & 15 & 33 & 11 \\
\hline High (More than 8) & 19 & 6.33 & 5 & 1.66 & 14 & 4.67 \\
\hline \multicolumn{7}{|c|}{ Farm Equipment Possession } \\
\hline Sickle & 300 & 100 & 150 & 100 & 150 & 100 \\
\hline Plough & 120 & 45 & 52 & 34.67 & 68 & 45.33 \\
\hline Land leveler & 264 & 88 & 121 & 80.67 & 143 & 95.33 \\
\hline Shovel & 300 & 100 & 150 & 100 & 150 & 100 \\
\hline *Multiple responses were all & \multicolumn{6}{|c|}{ Training Exposure } \\
\hline No training & 193 & 64.33 & 105 & 70 & 88 & 58.67 \\
\hline One to two & 74 & 24.67 & 35 & 23.33 & 39 & 26 \\
\hline Three or more & 33 & 11 & 10 & 6.67 & 23 & 15.33 \\
\hline \multicolumn{7}{|c|}{ Information Seeking Behaviour } \\
\hline Low (Up to 11) & 102 & 34 & 82 & 54.67 & 20 & 13.33 \\
\hline Medium (12-35) & 153 & 51 & 54 & 36 & 99 & 66 \\
\hline High (More than 35) & 45 & 15 & 14 & 9.33 & 31 & 20.67 \\
\hline
\end{tabular}

